\title{
DETERMINANT FACTORS ON STUNTING INCIDENCE AMONG CHILDREN AGE 6-24 MONTHS, PEMALANG, CENTRAL JAVA: A CASE STUDY
}

\author{
Arwinda Nugraheni, Ani Margawati, Firdaus Wahyudi, \\ Dea Amarilisa Adespin, Bambang Hariyana
}

Faculty of Medicine, Universitas Diponegoro

\begin{abstract}
Background: Stunting among children under five can be caused by various factors, including inadequate food intake, characteristics of children, history of infectious diseases, family care pattern, and quality of health services. The dominant cause of stunting is different in each region. This study aimed to determinant the factors on stunting incidence among children age 624 months, Pemalang, Central Java.

Subjects and Method: This was a case control study conducted in July 2019 in the work area of the Kebondalem Community Health Center in Pemalang, Central Java. A total of 142 stunted children aged 6-24 months were selected for this study. The dependent variable of this study was stunting. The independent variables were nutritional intake, immunization status, hygene, exclusive breastfeeding, parental education, occupation, family income, and a history of infectious diseases. Data were collected using anthropometric measurements and interviews with a questionnaire. Data were analyzed using logistic regression.

Results: Mother's occupation $(\mathrm{OR}=0.26 ; 95 \% \mathrm{CI}=0.01$ to $0.78 ; \mathrm{p}=0.035$;), history of exclusive breastfeeding $(\mathrm{OR}=0.07 ; 95 \% \mathrm{CI}=0.02$ to $0.25 ; \mathrm{p}=0.001)$, history of infectious disease $(\mathrm{OR}=0.008 ; 95 \% \mathrm{CI}=0.02-0.25 ; \mathrm{p}=0.010)$, Nutritional intake $(\mathrm{OR}=9.44 ; 95 \% \mathrm{CI}=1.88$ to $47.43 ; \mathrm{p}=0.006)$, and they were statistically significant.

Conclusion: Mother's occupation, history of exclusive breastfeeding, history of disease infection, and nutritional intake are factors associated with the risk of stunting.
\end{abstract}

Keywords: mother's occupation, history of exclusive breastfeeding, history of disease infection, and nutritional intake, stunting

\section{Correspondence:}

Arwinda Nugraheni. Faculty of Medicine, Universitas Diponegoro, Yogyakarta, Indonesia. Email: arwindanugraheni@gmail.com 